\title{
Letter
}

\section{Structure-Activity Relationship for the Oxadiazole Class of Antibacterials}

Marc A. Boudreau, Derong Ding, Jayda E. Meisel, Jeshina Janardhanan, Edward

Spink, Zhihong Peng, Yuanyuan Qian, Takao Yamaguchi, Sebastian A. Testero,

Peter I. O'Daniel, Erika Leemans, Elena Lastochkin, Wei Song, Valerie A. Schroeder, William R. Wolter, Mark A. Suckow, Shahriar Mobashery, and Mayland Chang

ACS Med. Chem. Lett., Just Accepted Manuscript • DOI: 10.1021/acsmedchemlett.9b00379 • Publication Date (Web): 03 Oct 2019

Downloaded from pubs.acs.org on October 4, 2019

\section{Just Accepted}

"Just Accepted" manuscripts have been peer-reviewed and accepted for publication. They are posted online prior to technical editing, formatting for publication and author proofing. The American Chemical Society provides "Just Accepted" as a service to the research community to expedite the dissemination of scientific material as soon as possible after acceptance. "Just Accepted" manuscripts appear in full in PDF format accompanied by an HTML abstract. "Just Accepted" manuscripts have been fully peer reviewed, but should not be considered the official version of record. They are citable by the Digital Object Identifier (DOI $\left.{ }^{\circ}\right)$. "Just Accepted" is an optional service offered to authors. Therefore, the "Just Accepted" Web site may not include all articles that will be published in the journal. After a manuscript is technically edited and formatted, it will be removed from the "Just Accepted" Web site and published as an ASAP article. Note that technical editing may introduce minor changes to the manuscript text and/or graphics which could affect content, and all legal disclaimers and ethical guidelines that apply to the journal pertain. ACS cannot be held responsible for errors or consequences arising from the use of information contained in these "Just Accepted" manuscripts. 


\title{
Structure-Activity Relationship for the Oxadiazole Class of Antibacterials
}

\author{
Marc A. Boudreau ${ }^{\dagger}$, Derong Ding ${ }^{\dagger}$, Jayda E. Meisel ${ }^{\dagger}$, Jeshina Janardhanan ${ }^{\dagger}$, Edward Spink ${ }^{\dagger}$, Zhihong \\ Peng ${ }^{\dagger}$, Yuanyuan Qian ${ }^{\dagger}$, Takao Yamaguchi ${ }^{\dagger}$, Sebastian A. Testero ${ }^{\dagger}$, Peter I. O’Daniel ${ }^{\dagger}$, Erika Leemans ${ }^{\dagger}$, \\ Elena Lastochkin ${ }^{\dagger}$, Wei Song ${ }^{\dagger}$, Valerie A. Schroeder ${ }^{\ddagger}$, William R. Wolter ${ }^{\ddagger}$, Mark A. Suckow ${ }^{\ddagger}$, Shahriar \\ Mobashery $^{\dagger *}$, and Mayland Chang ${ }^{\dagger *}$
}

`Department of Chemistry and Biochemistry, University of Notre Dame, Notre Dame, IN 46556
"Freimann Life Sciences Center and Department of Biological Sciences, University of Notre Dame, Notre Dame, IN 46556
KEYWORDS antibacterials, oxadiazoles, penicillin-binding proteins, structure-activity relationship

ABSTRACT: A structure-activity relationship (SAR) for the oxadiazole class of antibacterials was evaluated by syntheses of 72 analogs and determination of the minimal-inhibitory concentrations (MICs) against the ESKAPE panel of bacteria. Selected compounds were further evaluated for in vitro toxicity, plasma protein binding, pharmacokinetics (PK), and a mouse model of methicillin-resistant Staphylococcus aureus (MRSA) infection. Oxadiazole 72c showed potent in vitro antibacterial activity, exhibits low clearance, a high volume of distribution, $41 \%$ oral bioavailability, and shows efficacy in mouse models of MRSA infection.

Antibiotics have been called miracle drugs. Not only have they saved millions of lives in treatment of infections, they have also made possible other medical interventions such as surgery, dialysis, and organ transplantation. The availability of antibiotics has contributed to the increase in life expectancy in the United States from 59.7 years in 1930 to 78.8 years in $2010 .{ }^{1}$ Notwithstanding, emergence of resistance to any antibiotic is inevitable, threatening viability of any given class of such agents. Among Gram-positive bacteria, resistant Staphylococcus aureus and Enterococci pose the biggest threat. ${ }^{2} S$. aureus is a leading cause of health-related infections. Every year in the United States more than 80,000 severe methicillin-resistant $S$. aureus (MRSA) infections occur, resulting in 11,285 annual deaths. ${ }^{3}$ Enterococci cause infections, including endocarditis, urinary-tract infections, and wound infections. Over 66,000 Enterococcus infections are reported every year in the United States, of which 20,000 are vancomycin-resistant Enterococcus (VRE), resulting in 1,300 deaths. ${ }^{3}$ The limited pipeline of new antibiotics has exacerbated the antibiotic-resistance crisis.

The oxadiazoles are a newly discovered class of non- $\beta$-lactam antibiotics targeting cell-wall biosynthesis. ${ }^{4}$ These antibiotics show potent bactericidal activity against difficult-to-treat Gram-positive bacteria, including MRSA and VRE. They do not have Gram-negative antibacterial activity. Our initial studies into this class of antibiotics produced lead compounds $\mathbf{1}-\mathbf{3}$, of which $\mathbf{2}$ and $\mathbf{3}$ exhibit $100 \%$ oral bioavailability and in vivo efficacy. ${ }^{4}$ Further studies on compound $\mathbf{2}$ suggested inhibition of the penicillin-binding proteins (PBPs) of S. aureus, which are responsible for bacterial cell-wall biosynthesis. ${ }^{4}$
With a view to explore the structural space of this class of antibiotics, we recently reported a structure-activity relationship (SAR) of the oxadiazoles against $S$. aureus ${ }^{5}$ with a focus on modifications in ring A. We found that 4-phenol, 4chloropyrazole, or 5-indole substitutions were generally favored at this position (1, 2, and 4-8; Figure 1). These compounds exhibit minimal-inhibitory concentration (MIC) values against $S$. aureus ranging from 0.5 to $4 \mu \mathrm{g} / \mathrm{mL}$. Furthermore, antibiotic 8 gave excellent efficacy in MRSAinfected mice comparable to results obtained with linezolid, the gold standard, and exhibited oral bioavailability and low toxicity. ${ }^{5-6}$

We report herein the synthesis and SAR results against $S$. aureus of 72 synthetic oxadiazoles with modifications in ring D (see Figure 1 for ring designations). To enable a comparison to our previously reported active compounds, we have limited our discussion in this report to compounds with the aforementioned ring A modifications. The SAR was established by initial screening of the synthetic derivatives against the ESKAPE panel of bacteria. This panel is comprised of Enterococcus faecium, Staphylococcus aureus, Klebsiella pneumoniae, Acinetobacter baumannii, Pseudomonas aeruginosa, and Enterobacter sp., and Escherichia coli. These bacteria account for the majority of problematic human infections. ${ }^{7}$ Selected compounds were further evaluated for in vitro toxicity, plasma protein binding, pharmacokinetics (PK), and in mouse models of MRSA infection.

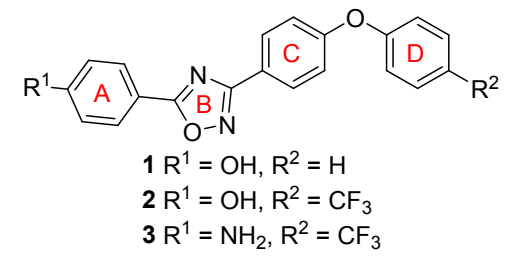

$2 \mathrm{R}^{1}=\mathrm{OH}, \mathrm{R}^{2}=\mathrm{CF}_{3}$
$3 \mathrm{R}^{1}=\mathrm{NH}_{2}, \mathrm{R}^{2}=\mathrm{CF}_{3}$

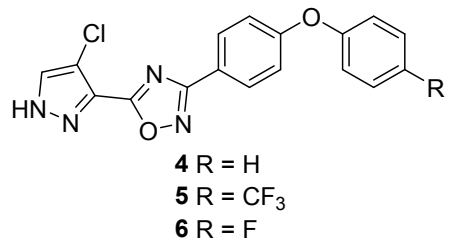

ACS Paragon Plus Environment

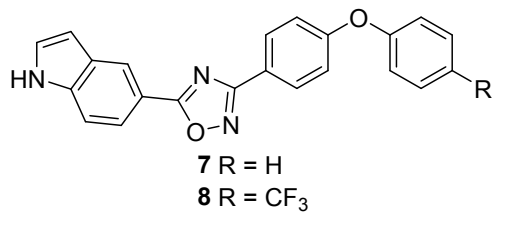


Figure 1. Structures of oxadiazoles active against $S$. aureus

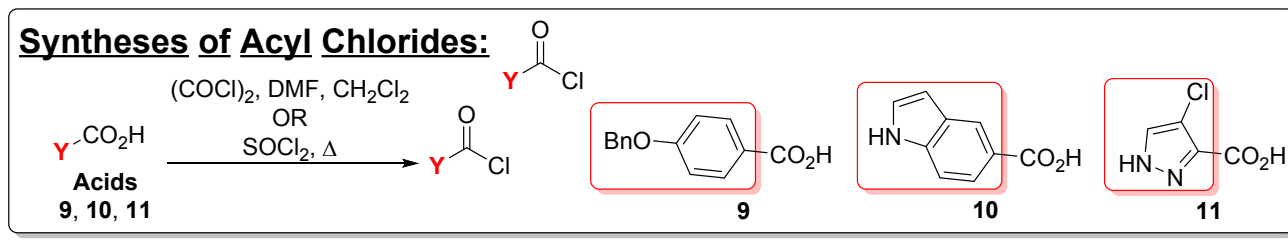

Syntheses of $\frac{\mathbf{N}^{\prime} \text {-Hydroxybenzimidamides: }}{\text { Nucleophilic substitution }^{a}} \mathrm{H}_{2} \mathrm{~N} \mathrm{~T}^{\mathrm{Z}}$

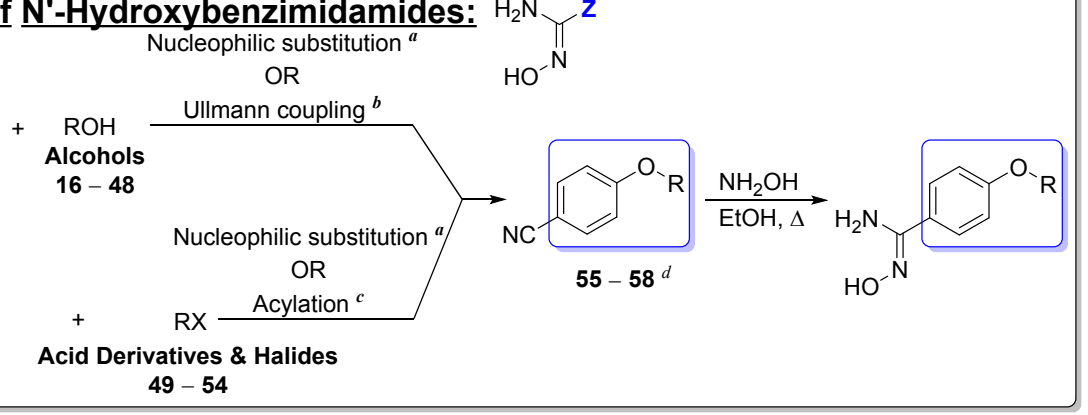

\section{Syntheses of Oxadiazoles $\stackrel{e}{:}$}<smiles>O=C(Cl)[C@@H]1[CH]CCC1</smiles><smiles>[Z]C1CCCC1=NO</smiles><smiles>[Mg][Mg]</smiles>

$\mathbf{X}=$ Halogen 12: $X=4-F$ 13: $X=4-1$

14: $X=3-F, 4-F$<smiles>N#Cc1ccc(O)cc1</smiles>

Acid Derivatives \& Halides $49-54$

\section{Starting Materials}

Alcohols

$\mathrm{HO}$

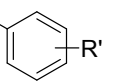

16: $\mathrm{R}^{\prime}=3-\mathrm{F}, 4-\mathrm{F}$

17: $\mathrm{R}^{\prime}=3-\mathrm{Cl}, 4-\mathrm{Cl}$

18: $R^{\prime}=4-I$

19: $\mathrm{R}^{\prime}=4-\mathrm{OCF}_{3}$

20: $\mathrm{R}^{\prime}=4-\mathrm{Br}$

21: $R^{\prime}=3-I$

22: $R^{\prime}=2-I$

23: $\mathrm{R}^{\prime}=4-\mathrm{OCH}_{3}$
24: $\mathrm{R}^{\prime}=4-\mathrm{COCF}_{3} \quad \mathrm{HO}$

26: $R^{\prime}=4-F$

27: $\mathrm{R}^{\prime}=3-\mathrm{Br}$

28: $\mathrm{R}^{\prime}=4-\mathrm{SO}_{2} \mathrm{CH}_{3}$

29: $\mathrm{R}^{\prime}=4-\mathrm{COCH}_{3}$

30: $\mathrm{R}^{\prime}=2-\mathrm{Br}, 4-\mathrm{F}$

31: $\mathrm{R}^{\prime}=2-\mathrm{Br}, 4-\mathrm{OCH}_{3}$

3: $\mathrm{R}^{\prime}=2-\mathrm{Br}$

$=2-\mathrm{Br}, 4-\mathrm{CF}_{3}$

35: $\mathrm{R}^{\prime}=2-\mathrm{OH}$

$\mathrm{HO}\left(\mathrm{CH}_{2}\right)_{3} \mathrm{NHBOC} 36$
25: $\mathrm{R}^{\prime}=3-\mathrm{Cl}, 4-\mathrm{F}$

32: $\mathrm{R}^{\prime}=2-\mathrm{Br}, 4-\mathrm{OCF}_{3}$<smiles>Cc1ccc2sc([Bi])nc2c1</smiles><smiles>Oc1ccccc1</smiles><smiles>[R]C1CCCC1</smiles>

41: $R^{\prime}=N B o c$ 42: $R^{\prime}=O$ 43: $\mathrm{R}^{\prime}=\mathrm{CH}_{2}$<smiles>OC1CC[R]CC1</smiles>

39: $\mathrm{R}^{\prime}=\mathrm{NBoc}$ 40: $\mathrm{R}^{\prime}=\mathrm{CHNHBoc}$

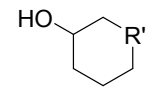

44: $\mathrm{R}^{\prime}=\mathrm{NBoc}$ 45: $\mathrm{R}^{\prime}=\mathrm{NCH}_{3}$

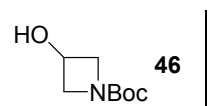<smiles></smiles><smiles>OC1CN2CCC1CC2</smiles>
$\widehat{C}_{N} 47$
Acid Derivatives \& Halides

Figure 2. General synthetic routes to access the 1,2,4-oxadiazoles, and the starting materials used for variations within ring D. ${ }^{a}$ Nucleophilic substitution: $\mathrm{NaH} / \mathrm{K}_{2} \mathrm{CO}_{3}$, DMSO/DMF, $60-100{ }^{\circ} \mathrm{C}$, overnight; ${ }^{b}$ Ullmann coupling: $\mathrm{CuI}, \mathrm{Cs}_{2} \mathrm{CO}_{3}, N, N$-dimethylglycine $\cdot \mathrm{HCl}, 1,4$-dioxane, $90{ }^{\circ} \mathrm{C}, 2-5 \mathrm{~h} ;{ }^{c}$ Acylation: anhydrous pyridine, $0{ }^{\circ} \mathrm{C}$ to rt, $4-6 \mathrm{~h} ;{ }^{d}$ Outliers like dibenzo[b,d]furan and dibenzo[b,e][1,4]dioxine are not listed for simplicity of the graph. Compounds $55-\mathbf{5 8}$ are 4-cyanophenyl ethers purchased commercially; ${ }^{e}$ Additional modifications are listed in Supporting Information.

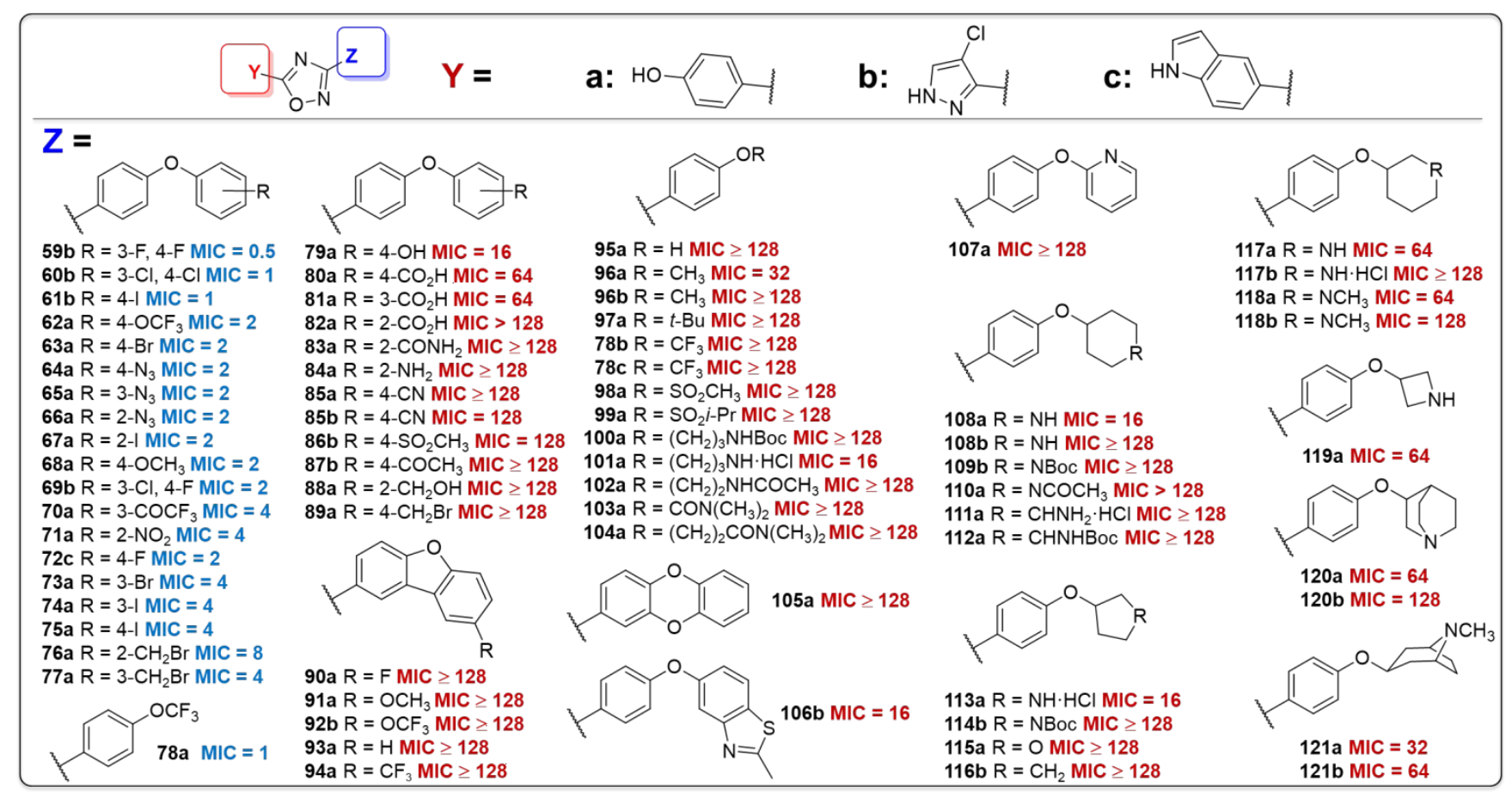

Figure 3. Antibacterial activities of the synthetic 1,2,4-oxadiazole derivatives with modifications of ring D. The $\mathrm{MIC}$ values (in $\mu \mathrm{g} / \mathrm{mL}$ ) measured for $S$. aureus ATCC 29213, with MIC of active compounds denoted in blue (MIC $\leq 8 \mu \mathrm{g} / \mathrm{mL}$ ) and inactive ones in red (MIC $>8$ $\mu \mathrm{g} / \mathrm{mL})$. 
The general synthetic routes to the oxadiazoles have been described previously. ${ }^{4-5}$ The same approach was used to access the analogs reported herein, except our focus was on modification of ring D, which necessitated diversification of the structures at the stage of the diphenyl ether construction. This was achieved either by direct nucleophilic substitution and Ullmann coupling reactions of nitriles 12-14 or direct nucleophilic substitution and acylation of 4hydroxybenzonitrile 15 (Figure 2). In many cases, ring D variations could be introduced by using commercially available substituted phenols $(\mathbf{1 6}-\mathbf{4 8})$, carboxylic acid derivatives $(\mathbf{5 0}, \mathbf{5 1}, 53$ and 54$)$ or halides (49 and 52). The substituents of several of these analogs could be used as synthetic handles for further elaboration, the reactions of which are described in the Supporting Information. In some cases where ring D was replaced by non-annular substituents, the requisite ethers were purchased $(\mathbf{5 5}-\mathbf{5 8})$.

We established the SAR for the oxadiazoles by screening them for antibacterial activity against the aforementioned ESKAPE panel of bacteria. The analogs reported herein show activity against Gram-positive bacteria. We specifically focused our attention on the analogs that exhibited activity against $S$. aureus (Figure 3).

In general, hydrophobic substituents, and especially halogens, were well-tolerated in ring D. Addition of an extra fluorine (59b) or chlorine $(69 b)$ at the 3-position retained activity in the 4-chloropyrazole series, as did substitution by two chlorines at these same positions (60b). Replacement of the fluorine by an iodine, either at position $4(\mathbf{6 1 b}, \mathbf{7 5 a})$, position $3(\mathbf{7 4 a})$, or position 2 (67a) also retained activity overall. The same trend was observed with introduction of a bromine atom at position 4 (63a) or position 3 (73a). Introduction of a trifluoromethoxy or methoxy group at position 4 of the ring $(\mathbf{6 2 a}, \mathbf{6 8 a})$ also retained activity, as did the presence of a 3-trifluoromethyl ketone substituent (70a). An azide group at any position of the ring also maintained a favorable MIC against $S$. aureus (64a, 65a, 66a). Interestingly, a benzylic bromide at position 2 (76a) or position 3 (77a) of the ring did not result in a noticeable increase in MIC, but introduction of this substituent at position 4 (89a) completely abolished activity.

We also explored the effect of tethering rings $\mathrm{C}$ and $\mathrm{D}$ at their respective 2-positions to form a dibenzofuran, and we found that the resulting compounds where ring A was a phenol were inactive when ring D was unsubstituted (93a) or substituted with a 4-trifluoromethyl group (94a), 4-fluoro (90a), 4methoxy (91a), or 4-trifluoromethoxy (92b). Likewise, expanding the furan portion with a heteroatom to form dibenzodioxine 105a resulted in loss of activity.

Replacing ring D with linear alkyl substituents resulted in only one active compound, the trifluoromethoxy derivative 78a, which contains a phenol for ring A. However, changing ring $\mathrm{A}$ to a 4-chloropyrazole (78b) or an indole (78c) resulted in loss of activity. The reasons for this are not clear at present. Other alkyl substituents introduced as surrogates for ring $\mathrm{D}$, such as methyl (96a, 96b) and tert-butyl (97a) gave compounds with poor activity, as did sulfonates (98a, 99a), alkylcarbamates (100a) and amines (101a), and amides (102a, 103a, 104a).

We observed that introducing partially or fully saturated systems at ring D gave compounds with good activity in a few cases. Introduction of a nitrogen atom to give 3-pyrrolidines 113a and 114b, or of an oxygen atom to give 3-tetrahydrofuran 115a, decreased or abolished the activity. As a general trend, introduction of hydrogen-bond-donating substituents at ring D resulted in compounds with decreased antimicrobial activity against $S$. aureus. Thus, the 4-phenol derivative 79a was only modestly active (MIC $=16 \mu \mathrm{g} / \mathrm{mL})$, and 2-benzyl alcohol 88a exhibited no activity. Similarly, benzoic acid derivatives 80a, 81a, and 82a were either poorly active or inactive, and 2carboxamide 83a and 2-aniline 84a were inactive. Introduction of polar substituents onto an aliphatic system also resulted in compounds with no activity, as observed with 4aminocyclohexane derivatives 111a, and 112a. Electronwithdrawing substituents introduced onto ring $\mathrm{D}$ also resulted in compounds with no activity, as evidenced by 4-benzonitriles $\mathbf{8 5 a}$ and $\mathbf{8 5 b}$, as well as 4-methylsulfonate $\mathbf{8 6 \mathbf { b }}$ and 4-acetate $\mathbf{8 7 b}$. One exception is 2-nitro derivative 71a, which had an MIC of $4 \mu \mathrm{g} / \mathrm{mL}$ against $S$ aureus.

Replacement of the phenyl ring at position D with heteroaromatic systems was also detrimental to activity. Thus, benzothiazole derivative 106b was modestly active (MIC $=16$ $\mu \mathrm{g} / \mathrm{mL}$ ), while pyridine derivative 107a was inactive (MIC $>128 \mu \mathrm{g} / \mathrm{mL}$ ). We observed a similar trend with heteroaliphatic ring systems, such as 4-piperidines (108a, 108b, 109b, 110a), 3-piperidines (117a, 117b, 118a, 118b), 3-azetidines (119a), as well as the pyrrolidines and tetrahydrofuran discussed above. Finally, we introduced more complex aliphatic aminecontaining ring systems, giving quinuclidine derivatives 120a and $120 \mathrm{~b}$ and tropine derivatives 121a and 121b, however, these exhibited poor activity against $S$. aureus (MIC $\geq 32$ $\mu \mathrm{g} / \mathrm{mL})$.

Compounds 59b, 60b, 61b, 62a, 69b, 78a, and 72c were selected and further evaluated for in vitro toxicity using the XTT assay with HepG2 cells and hemolysis of red blood cells (Table 1). Compound 78a, in which the ring D was replaced with trifluoromethoxy caused $16 \%$ hemolysis at a concentration of $64 \mu \mathrm{g} / \mathrm{mL}$; no further studies were done with this compound. Plasma protein binding was between $90 \%$ to $99 \%$. Although high, it is within the range for $43 \%$ of the 1500 most frequently prescribed drugs,${ }^{8}$ including many antibiotics on the market such as daptomycin, oxacillin, teicoplanin, rifampicin, and clindamycin. ${ }^{9-12}$ Compounds 59b, 60b, 61b, 62a, and 69b showed $>1 \%$ hemolysis or $<35$ for the ratio of XTT/MIC and were not studied further.

Table 1. In vitro evaluation of oxadiazoles

\begin{tabular}{ccccc}
\hline & $\begin{array}{c}\text { MIC } \\
\boldsymbol{\mu g} / \mathbf{m L}\end{array}$ & $\begin{array}{c}\text { Human } \\
\text { plasma } \\
\text { protein } \\
\text { binding \% }\end{array}$ & $\begin{array}{c}\text { XTT IC } \\
(\boldsymbol{\mu g} / \mathbf{m L})\end{array}$ & $\begin{array}{c}\text { Hemolysis } \\
\text { \% }\end{array}$ \\
\hline $\mathbf{8}^{\mathbf{a}}$ & 2 & $98.2 \pm 3.2$ & $75.7 \pm 7.3$ & $<1$ \\
$\mathbf{5 9 b}$ & 0.5 & $98.9 \pm 1.6$ & $17.7 \pm 1.0$ & 1.3 \\
$\mathbf{6 0 b}$ & 1 & $97.8 \pm 0.3$ & $17.2 \pm 1.0$ & 1.8 \\
$\mathbf{6 1 b}$ & 1 & $90.5 \pm 0.3$ & $30.7 \pm 0.8$ & 3.1 \\
$\mathbf{6 2 a}$ & 2 & $99.8 \pm 0.1$ & $16.9 \pm 0.9$ & 2.1 \\
$\mathbf{6 9 b}$ & 2 & $91.2 \pm 0.6$ & $21.0 \pm 0.9$ & 2.9 \\
$\mathbf{7 8 a}$ & 1 & $\mathrm{ND}$ & $84.9 \pm 0.9$ & 16 \\
$\mathbf{7 2 c}$ & 1 & $98.8 \pm 0.7$ & $37.0 \pm 0.9$ & $<1$ \\
\hline
\end{tabular}

a Data from Spink et al., reproduced for comparison

Compound 72c was evaluated in a broader panel of Grampositive bacteria and compared to the previous lead oxadiazole 8 and the standards vancomycin and linezolid (Table 2). Oxadiazole 72c showed better activity against MRSA strains 
NRS70, VRS1, and VRS2, and S. haemolyticus, B. cereus, $B$.

licheniformis, and E. faecalis ATCC 29212 than oxadiazole 8.

Table 2. Activity of oxadiazoles against Gram-positive organisms. MIC in $\mu \mathrm{g} / \mathrm{mL}$.

Table 3. Pharmacokinetic parameters of $72 \mathrm{c}$ in mice

A PK study was conducted with $\mathbf{7 2 c}$ after intravenous (iv) and oral (po) administration (Figure 4). Oxadiazole 72c had low clearance of $7.8 \mathrm{~mL} / \mathrm{min} / \mathrm{kg}$, a large volume of distribution of $14.2 \mathrm{~L} / \mathrm{kg}$, and a long terminal half-life of $21.1 \mathrm{~h}$ after iv administration (Table 3 ). Maximum concentration of $1.0 \mu \mathrm{g} / \mathrm{mL}$ was achieved at $2.5 \mathrm{~h}$ and oral bioavailability was $41 \%$. Systemic exposure and oral bioavailability for $\mathbf{7 2 c}$ were generally lower than the corresponding parameters for oxadiazole 8. In addition, the half-life for distribution after iv administration for oxadiazole $\mathbf{8}$ was shorter than that for $\mathbf{7 2 c}$.

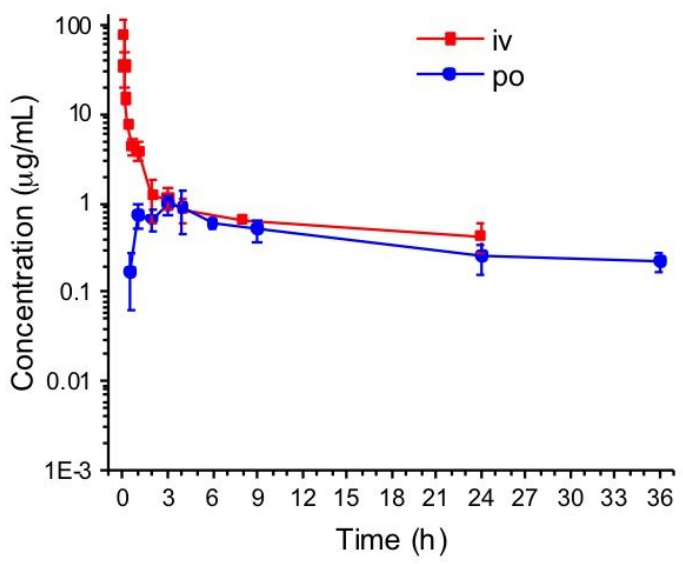

Figure 4. Pharmacokinetics of 72c after single iv and po administration at $20 \mathrm{mg} / \mathrm{kg}$ to mice ( $\mathrm{n}=3$ mice per time point).

${ }^{\mathrm{a}}$ Data from Spink et al., reproduced for comparison
8 vancomycin linezolid

\begin{tabular}{ccc}
4 & 1 & 2 \\
4 & 2 & 1 \\
2 & 1 & 1 \\
2 & 2 & 1 \\
2 & 1 & 32 \\
2 & 1 & 32 \\
2 & 64 & 1 \\
2 & 32 & 1 \\
2 & 4 & 0.5 \\
$4-8$ & 4 & 1 \\
16 & 1 & 0.5 \\
8 & 0.5 & 0.5 \\
8 & 2 & 1 \\
4 & 1 & 1 \\
4 & 128 & 1 \\
1 & 0.5 & 1 \\
2 & 128 & 1 \\
2 & 0.5 & 1 \\
\hline
\end{tabular}
aA quality-control strain to monitor accuracy of MIC testing; ${ }^{b} m e c A$ positive, resistant to methicillin, oxacillin,
and tetracycline; susceptible to vancomycin and linezolid; ${ }^{c} m e c A$ positive, resistant to ciprofloxacin, gentamicin, oxacillin, penicillin, and linezolid; ${ }^{\mathrm{v}}$ vancomycin-resistant MRSA (vanA) clinical isolate from Michigan; ${ }^{\mathrm{e}}$ vancomycin-resistant MRSA (vanA) clinical isolate from Pennsylvania; ${ }_{\mathrm{f}}$ vancomycin-susceptible clinical isolate; $\mathrm{g}_{\text {Vancomycin-resistant clinical isolate. }}$

\begin{tabular}{lcc}
\hline & $\mathbf{7 2 c}$ & $\mathbf{8}^{\mathbf{a}}$ \\
\hline Dose $20 \mathrm{mg} / \mathrm{kg}$ iv & & \\
$\mathrm{AUC}_{0}$ - ast & 1790 & 3140 \\
$(\mu \mathrm{M} \cdot \mathrm{min} / \mathrm{mL})$ & & \\
$\mathrm{AUC} \mathrm{C}_{0}(\mu \mathrm{M} \cdot \mathrm{min} / \mathrm{mL})$ & 2570 & 3520 \\
$\mathrm{CL}(\mathrm{ml} / \mathrm{min} / \mathrm{kg})$ & 7.8 & 5.7 \\
$\mathrm{~V}_{\mathrm{d}}(\mathrm{L} / \mathrm{kg})$ & 14.2 & 4.7 \\
$\mathrm{t}_{1 / 2} \operatorname{dist}(\mathrm{h})$ & 0.4 & 0.009 \\
$\mathrm{t}_{1 / 2}$ elim $(\mathrm{h})$ & 21.1 & 9.6 \\
\hline Dose $20 \mathrm{mg} / \mathrm{kg}$ po & & \\
$\mathrm{AUC}_{0}-\mathrm{last}$ & 718 & 3060 \\
$(\mu \mathrm{M} \cdot \mathrm{min} / \mathrm{mL})$ & & \\
$\mathrm{AUC}_{0-\infty}(\mu \mathrm{M} \cdot \mathrm{min} / \mathrm{mL})$ & 1040 & 4060 \\
$\mathrm{C}_{\text {max }}(\mu \mathrm{g} / \mathrm{mL})$ & 1.0 & 2.3 \\
$\mathrm{~T}_{\text {max }}(\mathrm{h})$ & 2.5 & 6 \\
$\mathrm{t}_{1 / 2}$ abs $(\mathrm{h})$ & 1.3 & 0.8 \\
$\mathrm{t}_{1 / 2} \operatorname{dist}(\mathrm{h})$ & 6.2 & 15.9 \\
$\mathrm{t}_{1 / 2}$ elim $(\mathrm{h})$ & 17.0 & 97 \\
$\mathrm{~F}(\%)$ & 41 & \\
\hline
\end{tabular}

Oxadiazole 72c was evaluated in the mouse peritonitis MRSA model of infection. The compound showed efficacy, with half of the mice surviving after two $20 \mathrm{mg} / \mathrm{kg}$ doses of the compound given iv at $30 \mathrm{~min}$ and $7.5 \mathrm{~h}$ after infection. Compound 72c was further evaluated in a mouse neutropenic thigh MRSA infection model using linezolid-sensitive (NRS70) and linezolid-resistant (NRS119) MRSA strains (Figure 5). The efficacy of $72 \mathrm{c}$ after a single oral dose at $40 \mathrm{mg} / \mathrm{kg}$ was comparable to that of compound 8 , with $1.1-\log$ and $1.5-\log$ reduction in bacterial count compared to vehicle in the NRS70 
and NRS119 strains, respectively. In the NRS119 study, bacterial counts after treatment with $\mathbf{7 2 c}$ and 8 were significantly lower $(p<0.05)$ than in the linezolid group. Drug concentrations at $48 \mathrm{~h}$ after a single oral $40 \mathrm{mg} / \mathrm{kg}$ dose of compound 8 were $7.6 \pm 2.3 \mu \mathrm{g} / \mathrm{g}$ and $6.0 \pm 1.2 \mu \mathrm{g} / \mathrm{g}$ in the NRS70 and NRS119 uninfected thighs, respectively (Table S5), which corresponded to 3- to 4-fold above MIC. Likewise, levels of compound $72 \mathrm{c}$ were $5.8 \pm 1.4 \mu \mathrm{g} / \mathrm{g}$ and $6.4 \pm 1.3 \mu \mathrm{g} / \mathrm{g}$ in the NRS70 and NRS119 uninfected thighs, respectively (Table S5), 6-fold above MIC. The levels of linezolid had dropped significantly and could not be quantified in the uninfected thighs. In summary, 72c showed potent in vitro activity against MRSA, oral bioavailability, and efficacy in mouse models of MRSA infection.

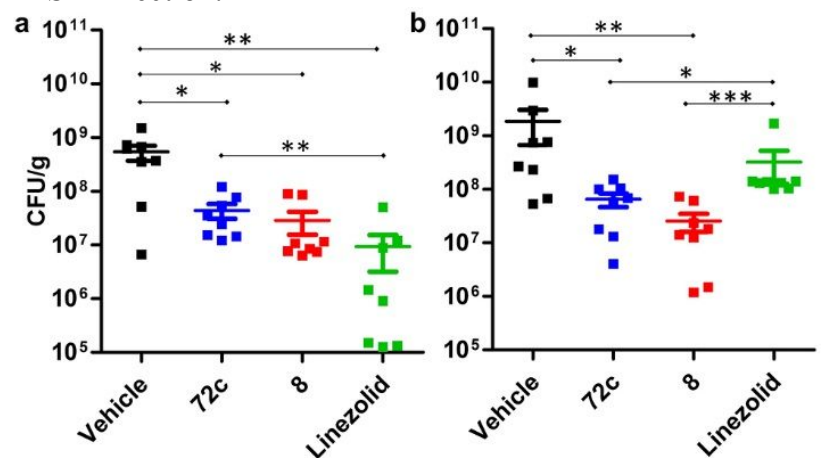

Figure 5. Efficacy of 72c in a mouse neutropenic thigh MRSA infection model using (a) NRS70 (linezolid-sensitive) and (b) NRS119 (linezolid-resistant). Mice ( $\mathrm{n}=8$ per group) were made neutropenic by administration of cyclophosphamide. Bacteria $\left(10^{5} \mathrm{cfu}\right)$ were injected intramuscularly into the right thigh. A single $40 \mathrm{mg} / \mathrm{kg}$ oral dose of vehicle, 72c, 8, or linezolid was given $1 \mathrm{~h}$ after infection. The thighs were harvested $48 \mathrm{~h}$ after infection, homogenized, and plated for colony counts. Mean $\pm \mathrm{SEM},{ }^{*} p<0.05,{ }^{* *} p<0.01, * * * p<0.001$ by Mann-Whitney U test two-paired.

\section{ASSOCIATED CONTENT}

\section{Supporting Information}

Synthetic procedures and experimental are supplied as Supporting Information. The Supporting Information is available free of charge on the ACS Publications website.

\section{AUTHOR INFORMATION}

\section{Corresponding Author}

* Shahriar Mobashery (mobashery@nd.edu) or Mayland Chang (mchang@,nd.edu)

\section{Author Contributions}

MAB, DD, ES, TY, SAT, PIO, and EL synthesized compounds. YQ conducted some of the MS and NMR work and helped in preparing the manuscript. JEM, ZP, and WS conducted plasma protein binding and PK. JEM determined drug concentrations in plasma and thighs in the mouse neutropenic thigh infection study. JJ conducted the mouse peritonitis and mouse neutropenic thigh infection studies and MIC against Gram-positive organisms. E. Lastochkin conducted MIC against the ESKAPE organisms and in vitro cytotoxicity. VAS, WRW, and MAS conducted the in-life portion of mouse peritonitis and PK studies. SM and MC designed the studies and wrote the manuscript, with contributions of all authors. All authors have given approval to the final version of the manuscript.

\section{Funding Sources}

This work was supported by grants AI090818 (to M.C. and S.M.) and by AI104987 (to S.M.) from the National Institutes of Health. YQ is a Ruth L. Kirschstein National Research Service Award Fellow of the Chemistry-Biochemistry-Biology Interface Program at the University of Notre Dame, supported by training grant T32 GM075762 from the National Institutes of Health.

\section{ACKNOWLEDGMENT}

We thank Pablo Cabrera for assistance with the syntheses of two analogs.

\section{ABBREVIATIONS}

AUC, area-under-the curve; iv, intravenous; MIC, minimalinhibitory concentration; MRSA, methicillin resistant Staphylococcus aureus; PK, pharmacokinetics; po, per os; SAR, structure-activity relationship; VRE, vancomycin-resistant Enterococci.

\section{REFERENCES}

1. National Center for Health Statistics. National Vital Statistics Report. http://www.infoplease.com/ipa/A0005148.html

2. Rossolini, G. M.; Arena, F.; Pecile, P.; Pollini, S., Update on the antibiotic resistance crisis. Curr. Opin. Pharmacol. 2014, 18, 56-60.

3. Centers for Disease Control and Prevention. Antibiotic Resistance Threats in the United States, 2013; 2013.

4. O'Daniel, P. I.; Peng, Z.; Pi, H.; Testero, S. A.; Ding, D.; Spink, E.; Leemans, E.; Boudreau, M. A.; Yamaguchi, T.; Schroeder, V. A.; Wolter, W. R.; Llarrull, L. I.; Song, W.; Lastochkin, E.; Kumarasiri, M.; Antunes, N. T.; Espahbodi, M.; Lichtenwalter, K.; Suckow, M. A.; Vakulenko, S.; Mobashery, S.; Chang, M., Discovery of a new class of nonbeta-lactam inhibitors of penicillin-binding proteins with Gram-positive antibacterial activity. J. Am. Chem. Soc. 2014, 136 (9), 3664-3672.

5. Spink, E.; Ding, D.; Peng, Z.; Boudreau, M. A.; Leemans, E.; Lastochkin, E.; Song, W.; Lichtenwalter, K.; O'Daniel, P. I.; Testero, S. A.; Pi, H.; Schroeder, V. A.; Wolter, W. R.; Antunes, N. T.; Suckow, M. A.; Vakulenko, S.; Chang, M.; Mobashery, S., Structure-activity relationship for the oxadiazole class of antibiotics. J. Med. Chem. 2015, 58 (3), 1380-1389.

6. Janardhanan, J.; Meisel, J. E.; Ding, D.; Schroeder, V. A.; Wolter, W. R.; Mobashery, S.; Chang, M., In Vitro and In Vivo Synergy of the Oxadiazole Class of Antibacterials with beta-Lactams. Antimicrob. Agents Chemother. 2016, 60, 5581-5588.

7. Boucher, H. W.; Talbot, G. H.; Bradley, J. S.; Edwards, J. E.; Gilbert, D.; Rice, L. B.; Scheld, M.; Spellberg, B.; Bartlett, J., Bad bugs, no drugs: no ESKAPE! An update from the Infectious Diseases Society of America. Clin. Infect. Dis. 2009, 48 (1), 1-12.

8. Kratochwil, N. A.; Huber, W.; Muller, F.; Kansy, M.; Gerber, P. R., Predicting plasma protein binding of drugs: a new approach. Biochem. Pharmacol. 2002, 64 (9), 13551374.

9. Dykhuizen, R. S.; Harvey, G.; Stephenson, N.; Nathwani, D.; Gould, I. M., Protein binding and serum bactericidal activities of vancomycin and teicoplanin. Antimicrob. Agents Chemother. 1995, 39 (8), 1842-1847.

10. Kochansky, C. J.; McMasters, D. R.; Lu, P.; Koeplinger, K. A.; Kerr, H. H.; Shou, M.; Korzekwa, K. R., Impact of pH on plasma protein binding in equilibrium dialysis. Mol. Pharm. 2008, 5 (3), 438-448. 
11. Lee, B. L.; Sachdeva, M.; Chambers, H. F., Effect of protein binding of daptomycin on MIC and antibacterial activity. Antimicrob. Agents Chemother. 1991, 35 (12), 2505-2508.

12. Sargent, P., Oxacillin for injection USP. Oxacillin package insert. 2013. 


\section{For Table of Contents Use Only}

Structure-Activity Relationship for the Oxadiazole Class of Antibacterials

Marc A. Boudreau ${ }^{\dagger}$, Derong Ding ${ }^{\dagger}$, Jayda E. Meisel ${ }^{\dagger}$, Jeshina Janardhanan ${ }^{\dagger}$, Edward Spink ${ }^{\dagger}$, Zhihong Peng ${ }^{\dagger}$, Yuanyuan Qian ${ }^{\dagger}$, Takao Yamaguchi ${ }^{\dagger}$, Sebastian A. Testero ${ }^{\dagger}$, Peter I. O'Daniel ${ }^{\dagger}$, Erika Leemans $^{\dagger}$, Elena Lastochkin ${ }^{\dagger}$, Wei Song ${ }^{\dagger}$, Valerie A. Schroeder ${ }^{\ddagger}$, William R. Wolter ${ }^{\ddagger}$, Mark A. Suckow, Shahriar Mobashery ${ }^{\dagger *}$, and Mayland Chang ${ }^{\dagger *}$

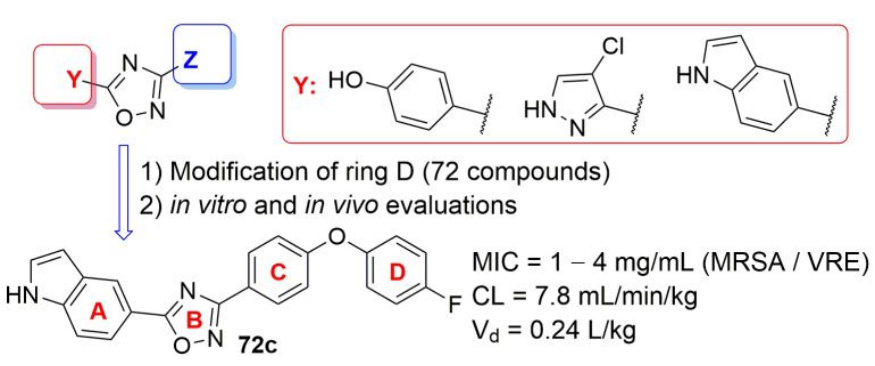

